\title{
Knowledge, Attitudes and Practices of Parents in the Vaso-Occlusive Crises of the Sick Children in Brazzaville
}

\author{
A. R. Okoko1,2, M. T. Eouolo1, J. Kambourou1,2, E. Moyen 1,2, G. Ekouya-Bowassa, ${ }^{1,2}$, B. Diall2, \\ A. Mbika-Cardorelle ${ }^{1,2}$, G. Moyen ${ }^{1,2}$ \\ ${ }^{1}$ Department of Pediatrics, Congo University Hospital, Brazzaville, Congo \\ ${ }^{2}$ Department of Doctoral Studies, Faculty of Health Sciences, Marien Ngouabi University, Brazzaville, Congo \\ Email: okoko_annie@yahoo.fr
}

How to cite this paper: Okoko, A.R., Eouolo, M.T., Kambourou, J., Moyen, E., Ekouya-Bowassa, G., Diall, B., Mbika-Cardorelle, A. and Moyen, G. (2017) Knowledge, Attitudes and Practices of Parents in the Vaso-Occlusive Crises of the Sick Children in Brazzaville. Open Journal of Pediatrics, 7, 205-213. https://doi.org/10.4236/ojped.2017.73024

Received: May 16, 2017

Accepted: September 24, 2017

Published: September 27, 2017

Copyright $\odot 2017$ by authors and Scientific Research Publishing Inc. This work is licensed under the Creative Commons Attribution International License (CC BY 4.0).

http://creativecommons.org/licenses/by/4.0/

\begin{abstract}
Objectives: to evaluate the parents' knowledge of vaso-occlusive crises, to identify their attitudes and practices. Method: a retrospective, transversal, descriptive and analytical study carried out between January and June 2016 at the HUC of Brazzaville. The parents of sickle cell children aged 2 to 17 years, followed for at least one year, were interviewed. Results: a total of 319 parents were interviewed, including 221 women (69.3\%) and 98 men (30.7\%) with a mean age of $40.8 \pm 9$ years. They were unschooled 65 cases $(20.4 \%)$, had primary education 41 cases (12.9\%), secondary 149 cases (46.7\%) and higher level 64 cases $(20.1 \%)$. They had one child sickle cell 258 cases $(80.9 \%)$. They knew sickle cell disease 283 cases (88.7\%), its genetic transmission 249 cases (78.1\%). The source of information was a health worker 211 cases $(66.1 \%)$. They had a good knowledge of the vaso-occlusive crisis 101 cases (31.7\%). In a vaso-occlusive crisis, they used a health facility 207 cases (64.8\%), self-medicated 66 cases $(20.7 \%)$. Their home practices were good 99 cases (31\%), fairly good 135 cases (42.3\%) and bad 85 cases (26.5\%). Parents aged 25 to $34(\mathrm{OR}=1.895 \% 1-3)$, secondary $(\mathrm{OR}=1.795 \% 1-2.7)$ and with good practices $(\mathrm{OR}=4.595 \% 2.7-7.5)$ are those who have a good knowledge of vaso-occlusive crises. Conclusion: The importance and severity of vaso-occlusive crises in the sickle-cell child's life experience, the crucial role played by parents in their care requires that the information, education and communication of these children be strengthened To improve their quality of life.
\end{abstract}

\section{Keywords}

Sickle-Cell Disease, Vaso-Occlusive Crises, Children, Knowledge, 
Attitudes, Practices, Brazzaville

\section{Introduction}

Sickle cell anemia, a hereditary disease related to a hemoglobin abnormality, is a public health problem [1] [2]. According to the World Health Organization (WHO), nearly 120 million people worldwide, or about 5\% of the population, carry the sickle cell trait and 500,000 children are born each sickle cell year, of which 200,000 in Africa [2].

In Africa, $10 \%-40 \%$ of the population would carry the sickle cell trait and about $2 \%$, homozygous [3].

In Congo, sickle cell disease varies between $20.7 \%$ and $23.5 \%$ and $1.2 \%$ of the population is homozygous [4].

Sickle cell anemia has a highly polymorphic and noisy clinical translation dominated by acute vaso-occlusive crises, the leading cause of sickle cell child morbidity [5]-[11]. Its management, currently well codified, rests among others on awareness, prevention and early detection [12].

The prevention of vaso-occlusive crises, an essential component of the secondary prevention of sickle cell disease, requires that the clinical manifestations, preventive measures and factors favoring the prevention of sickle cell disease are known to parents and sickle cell children.

To improve the quality of life of sickle-cell children, the objectives of this study were to assess parents' knowledge of vaso-occlusive crises, to identify their attitudes and practices in the face of vaso-occlusive crises.

\section{Methodology}

It was a retrospective, transversal, descriptive and analytical study carried out between January and June 2016, in 6 months, in the unit of follow-up of sickle-cell children of the Hospital and University Center (HUC) of Brazzaville.

Parents with homozygous sickle cell children aged 2 to 17 years who have been followed for at least 12 months and who have agreed to participate in the study have been included.

The selection of parents was made after a simple random draw. The sample size was calculated from the Schwartz formula:

$$
N=t^{2} \times p \times(1-p) / e^{2}
$$

$t$. reduced risk difference $\alpha=5 \%$ (corresponding to 1.96); e: margin of error set at $0.05 ; p$ : prevalence of homozygous sickle cell disease $=2 \%$.

A total of 319 parents meeting the inclusion criteria were selected.

The study variables were:

- Those related to the parents: age, sex, educational level and marital status; 
- Those relating to knowledge of sickle cell disease: the definition of sickle cell disease, the definition was good when it included the items "hereditary disease or blood disease", the mode of transmission, the source of information, clinical manifestations, Screening examinations, complications, preventive measures, signs requiring emergency consultation;

- Those relating to the knowledge of vaso-occlusive crises: their locations, clinical expression, triggers and means of prevention;

- Those relating to the attitude of parents to a vaso-occlusive crisis: the first-line appeal structure;

- Those relating to the quality of the parents' home practices in the face of a vaso-occlusive crisis.

\subsection{Criteria for Judgment}

In order to assess parental knowledge of vaso-occlusive crises, a grid was developed that included the following parameters (location, clinical manifestations, preventive measures and triggers). These parameters were composed of items rated at 1 each (Table 1) and the assessment of the overall knowledge of vaso-occlusive crises (Table 2).

Table 1. Level of knowledge of parents of vaso-occlusive crises.

\begin{tabular}{|c|c|c|c|c|}
\hline & \multirow{2}{*}{ Quote } & \multicolumn{3}{|c|}{ Knowledge } \\
\hline & & Good & Average & Low \\
\hline \multicolumn{5}{|c|}{ Location } \\
\hline Bone & 1 & \multirow{2}{*}{2} & \multirow{2}{*}{1} & \multirow{2}{*}{0} \\
\hline Abdominal & 1 & & & \\
\hline \multicolumn{5}{|c|}{ Clinical manifestations } \\
\hline Pains & 1 & \multirow{2}{*}{2} & \multirow{2}{*}{1} & \multirow{2}{*}{0} \\
\hline Swelling & 1 & & & \\
\hline \multicolumn{5}{|l|}{ Favorable factors } \\
\hline Cold & 1 & \multirow{7}{*}{$2=(5-7)$} & \multirow{7}{*}{$1=(2-4)$} & \multirow{7}{*}{$0=(<2)$} \\
\hline Fever & 1 & & & \\
\hline Dehydration & 1 & & & \\
\hline Stress & 1 & & & \\
\hline Physical effort & 1 & & & \\
\hline Beaten & 1 & & & \\
\hline Infection & 1 & & & \\
\hline \multicolumn{5}{|l|}{ Preventive measures } \\
\hline Warm clothing & 1 & \multirow{4}{*}{$2=(3-4)$} & \multirow{4}{*}{$1=(2)$} & \multirow{4}{*}{$0=(<2)$} \\
\hline Drinks abundant & 1 & & & \\
\hline Intense physical effort & 1 & & & \\
\hline Use of mosquito net & 1 & & & \\
\hline
\end{tabular}


Table 2. Overall knowledge of vaso-occlusive crises.

\begin{tabular}{ccccc}
\hline \multicolumn{4}{c}{ Overall knowledge of vaso-occlusive crises } \\
\hline Items & Quote & \multicolumn{3}{c}{ Knowledge } \\
\cline { 3 - 5 } & & Good & Average & Low \\
\hline Location & $0-2$ & & & \\
Clinical expressions & $0-2$ & & & \\
Factors triggering & $0-2$ & $6-8$ & $5-3$ & $<3$ \\
Means of prevention & $0-2$ & & & \\
\hline
\end{tabular}

In order to evaluate the practices of the parents at home, our criteria were as follows: the practice was said to be good when the parents used the three therapeutic means: hyper hydration, analgesics and anti inflammatory and/or anti spasmodic, Good enough for those who used two of these therapeutic means and bad for those who did not use any therapeutic means.

\subsection{Ethical Considerations}

The study protocol obtained the approval of the Committee of Ethics of Health Sciences Research: N041/MRSIT/IRSSA/CERSSA.

\subsection{Statistical Analysis}

The data mask, data processing and analysis were performed using SPSS software version 19 and Excel 2010. The statistical analysis was performed at two (2) levels: a univariate analysis to determine the frequency of each variable and A bi or multi varied to study the associations between the variables. Qualitative data, proportions and their associations were performed through the contingency tables with their significance measured by the Pearson chi-square test. Risk quantification was assessed by estimating the odds ratios (Odd-Ratio) with their $95 \%$ confidence intervals. However, a Pearson correlation was required to verify the existence or not of a relationship between a dependent variable $\mathrm{Y}$ considered independent with a dependent variable $\mathrm{X}$. The $p$ value of the probability was judged to be significant for a value less than 0.05 . Any exposure of an event to an Odd-ratio greater than 1 with a probability of less than $5 \%$ was considered to be at risk or high risk.

\section{Results}

\section{1) Socio-Demographic Characteristics of Parents}

The study population consisted of 319 parents aged an average of $40.8 \pm 9$ years (25 and 60 years). There were 221 women (69.3\%) and 98 men (30.7\%), unschooled 65 cases $(20.4 \%)$, with primary education 41 cases (12.9\%), Secondary education 149 cases $(46.7 \%)$ and higher level 64 cases $(20.1 \%)$. They were married 214 cases $(67.1 \%)$, singles 88 cases $(27.6 \%)$, widows 10 cases $(3.1 \%)$ and divorced 7 cases $(2.2 \%)$. They had one child with sickle cell disease 258 cases 
(80.9\%), two children 30 cases (9.4\%), three children and more 31 cases $(9.7 \%)$.

\section{2) Knowledge of Sickle Cell Disease}

Sickle cell disease was known by 283 parents $(88.7 \%)$, the definition given was good 258 cases $(80.9 \%)$. The known mode of transmission was genetic 249 cases (78.1\%). Hemoglobin electrophoresis was performed in 151 cases (47.3), Seriver Vaugh 95 cases (29.8\%), Emmel 66 cases (20.7\%). Sixty-eight (68) parents (21.3\%) had no screening for sickle cell disease. The parents' source of information was a health worker 211 cases $(66.1 \%)$, the media 71 cases $(22.3 \%)$, the family 50 cases $(15.7 \%)$ and the school 35 cases (11\%).

Clinical manifestations were pain 254 cases (76.9\%), fever 185 cases (58\%), jaundice 170 cases (53.3\%), swelling of the Hands and/or feet 151 cases (51.3\%), anemia 149 cases $(46.7 \%)$, and the delay of weight and height 80 cases $(25.1 \%)$. Thirty-seven parents (11.6\%) had no knowledge of the clinical manifestations of sickle cell disease.

The known complications were bone pain and anemia 99 cases (31\%) each, leg ulcer 58 cases $(18 \%)$, osteonecrosis of the femoral head 49 cases (15.4\%), stroke 33 cases $(10.4 \%)$ and priapism 20 cases (6.3\%). One hundred and fifty-five (48.6\%) parents had no knowledge of the complications of sickle cell disease. The means of preventing sickle-cell anemia cited by the parents were: the obligation of the prenuptial assessment 222 cases (69.6\%), the prohibition of consanguineous marriages 153 cases (47.9\%) and the screening before pregnancy 134 cases (42\%).

The signs requiring urgent consultation were pallor 225 cases (70.3\%), fever 202 cases $(63.3 \%)$, pain resistant to analgesics 201 cases $(63 \%)$, an increase in the volume of the abdomen 168 cases $(52.7 \%)$ and a change in staining of urine 163 cases $(51.1 \%)$.

\section{3) Knowledge of Vaso-Occlusive Crises}

The level of knowledge of localization, clinical expression, triggering factors, preventive measures and assessment of the overall knowledge of vaso-occlusive crises in the study population are shown in Table 3 and Table 4 and Figure 1.

Table 3. Knowledge of vaso-occlusive crises.

\begin{tabular}{cccc}
\hline Knowledge of CVOs & Good & Average & Low \\
\hline Location & $199(62.4 \%)$ & $83(26 \%)$ & $37(11.6 \%)$ \\
Clinical manifestations & $6(1.2 \%)$ & $186(58.3 \%)$ & $127(39.8 \%)$ \\
Favorable factors & $88(27.6 \%)$ & $135(42.3 \%)$ & $96(30.1 \%)$ \\
Preventative measures & $104(32.6 \%)$ & $112(35.1 \%)$ & $103(32.3 \%)$
\end{tabular}

Table 4. Overall knowledge of vaso-occlusive crises.

\begin{tabular}{cccccc}
\hline & Good & Average & OR & OR a & P \\
\hline$[25-34]$ & 32 & $\mathbf{4 5}$ & $\mathbf{1 . 8}[\mathbf{1}-\mathbf{3}]$ & $\mathbf{0 . 6}[\mathbf{0 . 4 - 1 . 1}]$ & $\mathbf{0 . 0 3 2 0 7}$ \\
Secondary & 56 & 93 & $1.7[1-2.7]$ & $0.4[0.3-0.6]$ & 0.03326 \\
Good practices & 74 & 25 & $2.1[1.2-3.8]$ & $4.5[2.7-7.5]$ & 0.0000 \\
\hline
\end{tabular}




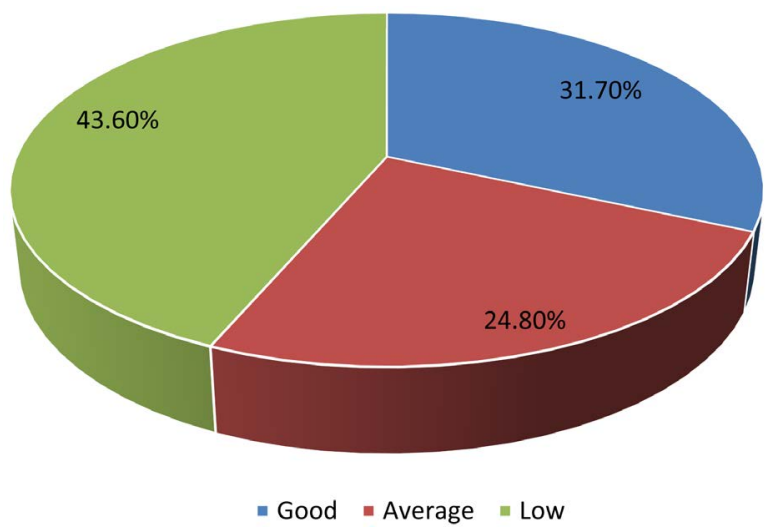

Figure 1. Overall knowledge of vaso-occlusive crises.

\section{4) Parental Attitudes and Practices in the Face of a Vaso-occlusive Crisis}

During a vaso-occlusive crisis, parents used a health facility in 207 cases (64.8\%), self-medicated 66 cases (20.7\%) and administered traditional treatment 46 cases (14.5\%). For those who consulted a health facility, their choice was in all cases guided by the quality and the existence of free treatment. The remoteness of the health facility, the cumulative experience in the management of sickle cell disease and the cost of hospitalization were reasons for not using a health facility.

Therapeutics administered at home were: abundant hydration 174 cases (54.5\%), analgesics 174 cases (72.1\%), anti-inflammatory and/or antispasmodic 226 cases $(70.9 \%)$, massages and applications of hot towels 59 cases $(18.5 \%)$.

Practices at home were considered good (31\%), average $(42.3 \%)$ and bad (26.7\%).

\section{5) Knowledge Determinants}

The determinants of knowledge of vaso-occlusive crises and their locations are shown in Table 4 and Table 5.

\section{Discussion}

The aim of this study was to assess the parents' knowledge of a vaso-occlusive sickle cell crisis, to identify their attitudes and practices in the face of vaso-occlusive crises.

From a sample of 319 parents divided into 221 women and 98 men, knowledge of sickle cell disease is required for 283 of them (88.7\%). The main known mode of transmission is genetic 249 cases (78.1\%). Knowledge of the vaso-occlusive crisis is good for 101 parents (31.7\%). The age range of 25 to 34 (OR $=1.8$ 95\% 1 - 3), secondary education $(\mathrm{OR}=1.795 \% 1-2.7)$, and good Practices $(\mathrm{OR}=4.595 \% 2.7-7.5)$ are the determinants of knowledge. Home practices are good 99 cases (31\%), fairly good 135 cases $(42.3 \%)$ and bad 85 cases (26.5\%).

\section{1) Sociodemographic Profile of the Study Population}

The child sickle cell in Brazzaville is willing to pay the mother (69.3\%). This is a constant in Africa, as reported earlier by us, Sangho et al. in Mali and Zola laina 
Table 5. Knowledge of the location of vaso-occlusive crises.

\begin{tabular}{cccccc}
\hline \multicolumn{5}{c}{ Knowledge of CVO location } \\
\hline & Good & Average & OR & ORa & P \\
\hline $25-34$ & 62 & 15 & $3.2[0.3-1.3]$ & $1.6[0.9-2.9]$ & 0.10564 \\
Male & 73 & 25 & $2.2[1.3-3.7]$ & $1.1[0.7-1.8]$ & 0.70765 \\
Superior & 54 & 10 & $4.1[2.4-12.8]$ & $2.2[1.1-4.3]$ & 0.02806 \\
1 child & 175 & 83 & $3.3[2.5-13.5]$ & $0.6[0.4-0.9]$ & 0.00787 \\
\hline
\end{tabular}

et al. in Madagascar [12] [13]. The usual proximity of mother and child on the one hand, and popular beliefs in Africa on the other, beliefs that the transmission of blood diseases is closely linked to the mother, justify their being guilty [14] and thus made responsible for their care.

The mean age of the parents estimated at 40.8 years in this study is like that reported by Assimadi et al. [15]: 39.6 years. Sangho et al. [12] report a younger population.

Parents have a secondary level in $46.7 \%$ of the cases and not in school $20 \%$, as in Togo: $34.9 \%$ of secondary level and $16 \%$ not schooled. On the other hand, in Madagascar, Zola Laina reports $60 \%$ of parents of secondary level and $4.4 \%$ of not schooled.

All the authors [12] [16] [17] agree that the parents in charge of the sickle cell child live in a couple as observed in $67.1 \%$ of the population of this study. However, fear and refusal of maternity after the discovery of the disease in the first child explain why $80.9 \%$ of these in Brazzaville and $69.5 \%$ in Togo [15] have only one child sickle cell. Eloundou et al. [17] noted the existence of a sickle cell child in 35\% of cases, Dione et al. [18]: 30\% and Diallo et al. [19]: 31\%.

\section{2) Knowledge of the Vaso-occlusive Crisis}

Knowledge of the vaso-occlusive crisis in Brazzaville is poor for $66.6 \%$ of parents, yet their main source of information is a health worker (66.1\%) (OR $=4.5$ $95 \% 1-2.7)$ and having good practices (OR $=4.595 \% 2.7-7.5)$. Parents aged between 25 and $34(\mathrm{OR}=1.895 \% 1-3)$, a secondary education $(\mathrm{OR}=1.795 \% 1$ - 2.7) and having good ( $\mathrm{OR}=4.595 \% 2.7$ - 7.5) have a significant knowledge of the vaso-occlusive crisis. It is also noted that having a sickle cell child ( $\mathrm{OR}=3.3$ $95 \% 2.5$ - 13.5) and higher education ( $\mathrm{OR}=4.195 \% 2.4$ - 12.8) influence Knowledge of the location of the vaso-occlusive crisis. And having more than one sickle cell child ( $\mathrm{OR}=4.995 \% 0.9$ - 27.9) improves knowledge of clinical manifestations. However, for Sangho et al. [12], the high level of education of mothers does not influence the knowledge and quality of management of vaso-occlusive crises. Knowledge of the factors favoring vaso-occlusive crises, an important aspect of prevention is good: $69.9 \%$. Exposure to cold is the most common factor (40.4\%). In Mali [18], knowledge of favorable factors is good for $78.6 \%$ of mothers.

\section{3) Parents' Attitudes to a Vaso-Occlusive Crisis}

In a vaso-occlusive crisis, the use of a health facility is $64.8 \%$ of the time. Rec- 
ognition of the UHCB as a center of reference and the effectiveness of free care justify this choice. But despite this good adhesion, the practice of self - medication and the use of traditional healers are noted in $14.5 \%$ of the cases.

\section{4) Parents' Practices in the Face of a Vaso-Occlusive Crisis}

This work shows that only $31 \%$ of parents have good practices. As knowledge of vaso-occlusive crises influences the practice ( $\mathrm{OR}=4.4,95 \% 2.7-7.5$ ), it is permissible for the rules of good practice to be taught at any consultation of the sickle cell child.

\section{Conclusion}

It follows from this study that parents have a poor knowledge of vaso-occlusive crises. The sickle cell follow-up unit is the first resort. Practices at home before a vaso-occlusive crisis are generally poor. The factors influencing knowledge of vaso-occlusive crises are: the age of parents between the ages of 25 and 34 years, secondary education and good practice.

\section{References}

[1] Mpemba Loufoua, A.B., Makoumbou, P., Mabiala Babela, J.R., Nakahonda, C., Mayanda, H.F. and Nzingoula, S. (2010) Dépistage néonatal de drépanocytose au Congo Brazzaville. [Neonatal Screening of Sickle Cell Disease in Congo Brazzaville.] Ann UnivMarienNgouabi, 11, 21-25.

[2] Modell, B. and Darlison, M. (2008) Global Epidemiology of Hemoglobin Disorders and Derived Service Indicator. Bull WHO, 86, 480-487.

https://doi.org/10.2471/BLT.06.036673

[3] WHO: Fifty-Ninth World Health Assemblies. Sickle Cell Disease. A59/9, 24 April 2016.

[4] Djembo Taty, M., Tchiloemba, M., Galacteros, F., Rosa, B. and Lissouba, P. (1986) Etude épidémiologique des hémoglobinopathies au Congo chez 2257 nouveau-nés. [Epidemiological Study of Hemoglobinopathies in the Congo in 2257 Newborns.] Nouv Rev Fr Hématol, 28, 249-251.

[5] Mbika-Cardorelle, A., Okoko, A. and Mouko, A. (2010) Les crises vaso-occlusives de l'enfant drépanocytaire à Brazzaville. [The Vaso-Occlusive Crises of the Sickle-Cell Child in Brazzaville.] ArchPediatr, 17, 295-296.

https://doi.org/10.1016/j.arcped.2009.11.009

[6] Mabiala-Babela, J.R., Nkanza-Kaluwako, S.A.T., Ganga-Zandzou, P.S., Nzingoula, S. and Senga, P. (2005) Causes d'hospitalisation d'enfants drépanocytaires: Influence de l'âge. [Causes of Hospitalization of Sickle Cell Children: Influence of Age.] Bull Soc Pathol Exot, 5, 392-393.

[7] Bennett, S.M. and Huntsman, E. (2000) Parent Perception of the Impact of Chronic Pain in Children and Adolescents. Child Health Care, 29, 147-159. https://doi.org/10.1207/S15326888CHC2903_1

[8] Conner-Warren, R.L. (1996) Pain Intensity and Home Pain Management of Children with Sickle Cell Disease. Pediatr Nurs, 19, 183-195.

[9] Bachir, D., Zemirline, F., Niakate, A., Cabaret, E. and Galactéros, F. (2015) Drépanocytose : le médecin du travail, relais essential dans l'information et la prise en charge. [Sickle-Cell Disease: The Occupational Physician, Essential Relay in Information and Management.] Arch Mal Profess Environn, 76, 373-385. 
https://doi.org/10.1016/j.admp.2015.04.003

[10] Moussavou, A., Vierin, Y., Eloundou-Orima, C. and Mboussou, K.M. (2004) Prise en charge de la douleur drépanocytaire selon les critères de l'OMS. [Management of Sickle Cell Pain According to WHO Criteria.] Arch Pediatr, 11, 1041-1045.

[11] HAS (2006) Prise en charge de la drépanocytose chez les enfants et les adolescents. [Management of Sickle Cell Disease in Children and Adolescents.] J PediatrPueric, 19, 71-81.

[12] Sangho, H., Dembélé Keita, H., Sibidi Keita, A., Yé Diarra, F., Belemou, B., et al. (2009) Enquête CAP sur la prise en charge de l'enfant drépanocytaire à Bamako. [CAP Survey on the Management of the Sickle Cell Child in Bamako.] Le Mali Medical, 24, 53-56.

[13] Zolalaina, R.A. (2013) Connaissances, Attitudes et Pratiques des parents face à la maladie drépanocytaire de leurs enfants [thèse]. [Knowledge, Attitudes and Practices of Parents in the Sickle Cell Disease of Their Children [Thesis].] Madagascar, 277.

[14] Montalembert, M. and Niakaté, A. (2009) Cross-Cultural Approach to the Neonatal Diagnosis of Sickle Cell Disease. Arch Pediatr, 16, 513-514.

[15] Assimadi, J.K., Gbadoé, A.D. and Nyadanu, M. (2000) L'impact familial de la drépanocytose au Togo. [The Family Impact of Sickle-Cell Anemia in Togo.] Arch Pédiatr, 7, 615-620.

[16] Kruti, A., Walsh, L.C. and Friedman, R.L. (2009) A Pilot Study to Explore Knowledge, Attitudes, and Beliefs about Sickle Cell Trait and Disease. J Nat Med Assoc, 101, 1163-1172.

[17] Eloundou, G.R.C. (2002) Prise en charge de la crise drépanocytaire selon des critères de l'OMS. Etude en milieu hospitalier pédiatrique à Libreville [Thèse médecine]. [Management of the Sickle Cell Crisis According to WHO Criteria. Study in Pediatric Hospital in Libreville [Thesis Medicine].] Libreville, Gabon.

[18] Dione, L. (2006) Les activités de l'unité fonctionnelle de prise en charge et de suivi des enfants drépanocytaires: Bilan d'une année [Thèse Médecine]. [Activities of the Functional Unit for the Care and Follow-Up of Sickle Cell Children: A One-Year Review [Thesis Medicine].] Mali.

[19] Diarra Assitan Doumbia (2003-2004) Suivi des enfants drépanocytaires de 0 à 15 ans dans le service de pédiatrie du CHU-GT [Thèse Médecine]. [Follow-Up of Sickle-Cell Children from 0 to 15 Years in the CHU-GT Pediatric Department [Thesis Medicine].] Mali.

[20] Traoré Rabia (2002) Prise en charge de la drépanocytose chez les enfants de o à 15 ans dans le service de pédiatrie de l'HGT (Bamako) [Thèse Médecine]. [Management of Sickle-Cell Anemia in Children Aged 0-15 Years in the Pediatric Department of the HGT (Bamako) [Thesis Medicine].] Mali. 
Submit or recommend next manuscript to SCIRP and we will provide best service for you:

Accepting pre-submission inquiries through Email, Facebook, LinkedIn, Twitter, etc. A wide selection of journals (inclusive of 9 subjects, more than 200 journals)

Providing 24-hour high-quality service

User-friendly online submission system

Fair and swift peer-review system

Efficient typesetting and proofreading procedure

Display of the result of downloads and visits, as well as the number of cited articles Maximum dissemination of your research work

Submit your manuscript at: http://papersubmission.scirp.org/

Or contact ojped@scirp.org 